\title{
Pengembangan Unit Bisnis Jasa Konsultasi Green Building di Universitas Widya Kartika
}

\author{
Ary Dwi Jatmiko ${ }^{\text {* }}$, dan Agustinus Angkoso' \\ ${ }^{1}$ Universitas Widya Kartika, Jl. Sutorejo Prima Utara II/1, Surabaya \\ *Email: arydeejee@,widyakartika.ac.id
}

\begin{abstract}
Abstrak
Beberapa tahun terkahir kita merasakan perubahan yang terjadi pada cuaca. Terjadi pergeseran dan perubahan tidak menentu. Diantaranya tingginya curah hujan dan tidak turun hanya pada musim penghujan, tetapi juga ditengah-tengah musim kemarau. Juga terjadinya kemarau yang berkepanjangan, dan peningkatan suhu. Hal ini adalah fenomena perubahan iklim, yang dipengaruhi oleh kadar gas rumah kaca melebihi batas. Semua hal ini dipengaruhi oleh kegiatan manusia, terutama peningkatan kebutuhan energi, yang dimana kebutuhan ini juga meningkatkan kadar karbon dioksida di atmosfir. Banyak terjadi gerakan untuk memperbaiki, atau mengurangi dampak itu semua. Salah satu gerakannya adalah Green Building. Kebutuhan untuk mewujudkan gedung ramah lingkungan meningkat di beberapa negara. Peluang inilah yang diambil oleh unit bisnis yang dibentuk di Universitas Widya Kartika. Unit bisnis yang diajukan ke dalam program PPUPIK yang didanai oleh Kemenristekdikti ini memiliki nama Green Building Widya Kartika. Unit ini merupakan kerja sama antara Program Studi Arsitektur dan Program Studi Teknik Sipil. Solusi yang diajukan yaitu peningkatan kompetensi sumber daya manusia dalam bidang Green Building, berperan aktif dalam komunitas Green Building, aktif melakukan sosialisasi, dan pelatihan, sebagai media promosi, serta meningkatkan kemampuan untuk membuat modeling bangunan dengan menggunanakan Building Information Modeling untuk kebutuhan simulasi. Dengan aktif di Green Building Council Indonesia, dipercaya untuk menjadi representatif Green Building Council Indonesia di Surabaya dan sekitar. Informasi terbaru dan peluang yang menyangkut Green Building, dapat didapat dengan mudah. Ditunjang dengan banyaknya tenaga ahli yang dimiliki dan penguasaan Building Information Modeling, menjadikan unit ini memiliki peluang yang besar.
\end{abstract}

Kata kunci: Building Information Modeling, Unit Bisnis, Arsitektur Hijau, Konstruksi Ramah Lingkungan.

\begin{abstract}
This is a new author guidelines and article template of Jurnal SOLMA LPPM UHAMKA publication. Article should be started by Title of Article followed by Authors Name and Affiliation Address and abstract. This abstract section should be typed in Times New Roman and font size of 10 pt and use not more than 250 words. The single spacing should be used between lines in this article. If article is written in Indonesian, the abstract should be typed in Indonesian and English. Meanwhile, if article is written in English, the abstract should be typed in English only. The abstract should be typed as concise as possible and should be composed of: problem statement, method, scientific finding results, and short conclusion. The abstract should only be typed in one paragraph and one-column format.
\end{abstract}

Keywords: Building Information Modeling, Business Unit, Green Architecture, Environmentally Friendly Construction.

Format Sitasi: Jatmiko A. \& Angkoso A. (2019). Pengembangan Unit Bisnis Jasa Konsultasi Green Building di Universitas Widya Kartika. Jurnal Solma, 08(1), 91-100. Doi: http://dx.doi.org/10.29405/solma.v8i1.2563

Diterima: 17 November 2018 | Revisi: 20 April 2019 | Dipublikasikan: 30 April 2019. 


\section{PENDAHULUAN}

Surabaya sebagai kota kedua terbesar mengalami pertumbuhan yang signifikan dalam pembangunan perumahan, pemukiman, gedung dan bagunan yang lain. Merupakan pangsa yang menarik di bidang konsultan. Seperti yang disampaikan oleh Ferry Salanto kepada Kompas.com. Selasa (13/1/2014), “Jika pada 2014, jumlah perkantoran secara kumulatif seluas 291.262 meter persegi, maka dalam kurun tiga tahun mendatang yakni 2015-2018 akan bertambah menjadi 800.000 meter persegi (Salanto, 2015). Jumlah ini berasal dari 19 gedung”. Hal ini tidak terjadi bukan hanya di Surabaya, tetapi juga provinsi Jawa Timur. Dengan dikeluarkan pedoman untuk menyelenggarakan bangunan gedung hijau (Kementrian Pekerjaan Umum dan Perumahan Rakyat Republik Indonesia), dengan no. 02/PRT/M/2015, maka semakin didorong kebutuhan untuk membangun gedung hijau.

Universitas Widya Kartika dalam hal ini mengembangkan PPUPIK Konsultan Green Building Widya Kartika (PPUPIK Konsultan GBWIKA) untuk mewadahi kebutuhan tersebut. Dalam hal ini Universitas memiliki sumber daya manusia dari berbagai bidang, meliputi arsitektur, sipil, elektro dan ekonomi, sehingga tinjauan yang dihasilkan akan semakin lengkap. Kita juga menyediakan jasa yang terintegrasi, mulai dari pendidikan atau pelatihan di bidang gambar, sampai jasa konsultasinya (Nofiyanti, Sulartiningrum, \& Fitriana, 2018). Selain itu belum ada lembaga pendidikan yang membuka pusat konsultasi bangunan hijau yang terintegrasi secara kegiatan dan keilmuan (teknik dan ekonomi).

Universitas Widya Kartika memiliki sudah Studio Komputer dan peralatan penunjangnya untuk mendukung kegiatan jasa konsultan tersebut. Saat ini banyak konsultan yang menangani konsultan untuk bangunan, tetapi kami memiliki keunggulan/keunikan sebagai berikut.

Tabel 1. Perbedaan PPUPIK Konsultan GBWIKA dengan provider pelatihan lain sejenis

\begin{tabular}{cccc}
\hline No & Indikator & \multicolumn{1}{c}{ PPUPIK Konsultan GBWIKA } & \multicolumn{1}{c}{ Konsultan lain } \\
\hline 1 & Materi & - Berfokus pada pengembangaan & - Menangani semua jenis \\
& & gedung hijau & gedung, tidak menfokuskan \\
& & - Meliputi perancangan desain dan & diri. \\
& & struktur & - Tidak tersedia training tenaga \\
& & - Menyediakan sampai dengan \\
& & kajian ekonomi & \\
& & - Menangani juga pengembangan & \\
& & tenaga kerja & \\
2 & Metode & - Konsultasi teknis & - Konsultasi teknis \\
& & - Konsultasi ekonomi &
\end{tabular}




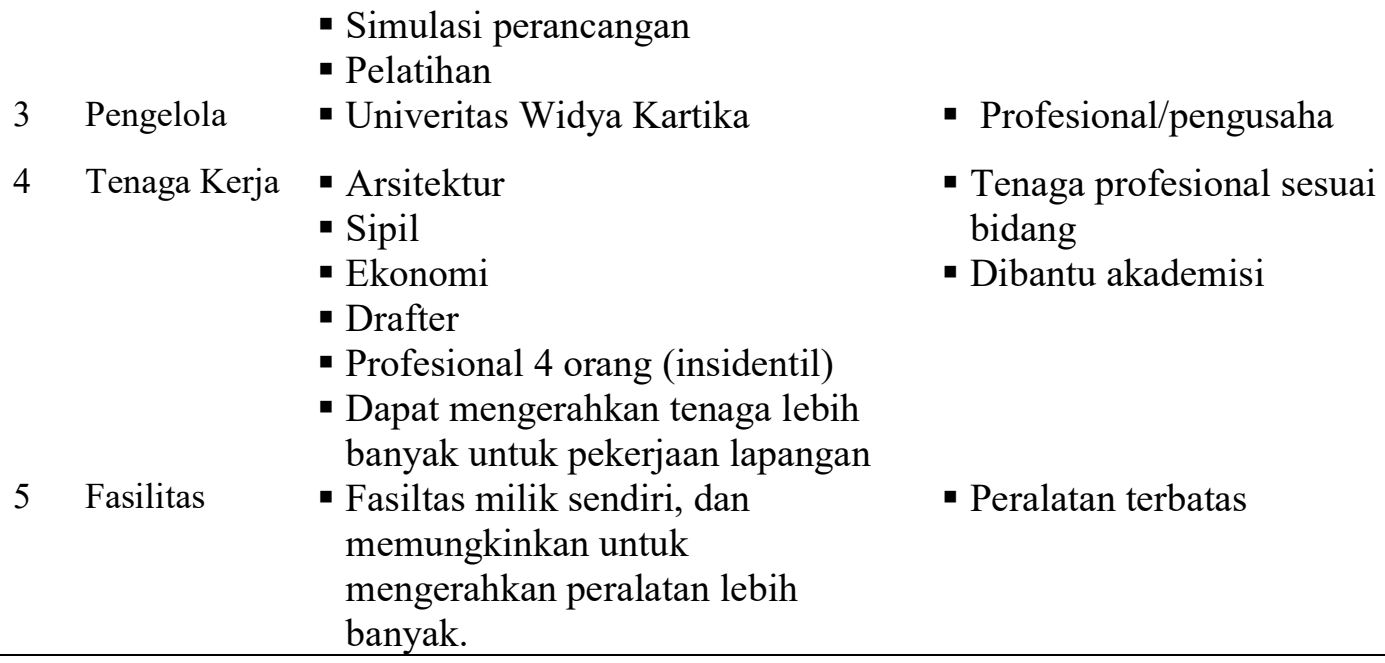

- Simulasi perancangan

- Pelatihan

3 Pengelola Univeritas Widya Kartika

4 Tenaga Kerja - Arsitektur

- Sipil

- Ekonomi

- Drafter

- Profesional 4 orang (insidentil)

- Dapat mengerahkan tenaga lebih banyak untuk pekerjaan lapangan

$5 \quad$ Fasilitas

- Profesional/pengusaha

- Tenaga profesional sesuai bidang

- Dibantu akademisi

- Fasiltas milik sendiri, dan memungkinkan untuk mengerahkan peralatan lebih banyak.

PPUPIK Konsultan GBWIKA memiliki beberapa produk yang saling menunjang dan terintegrasi antara keseluruhan produk. Berikut ini grafis tentang produk kami dan hubungan diantaranya :

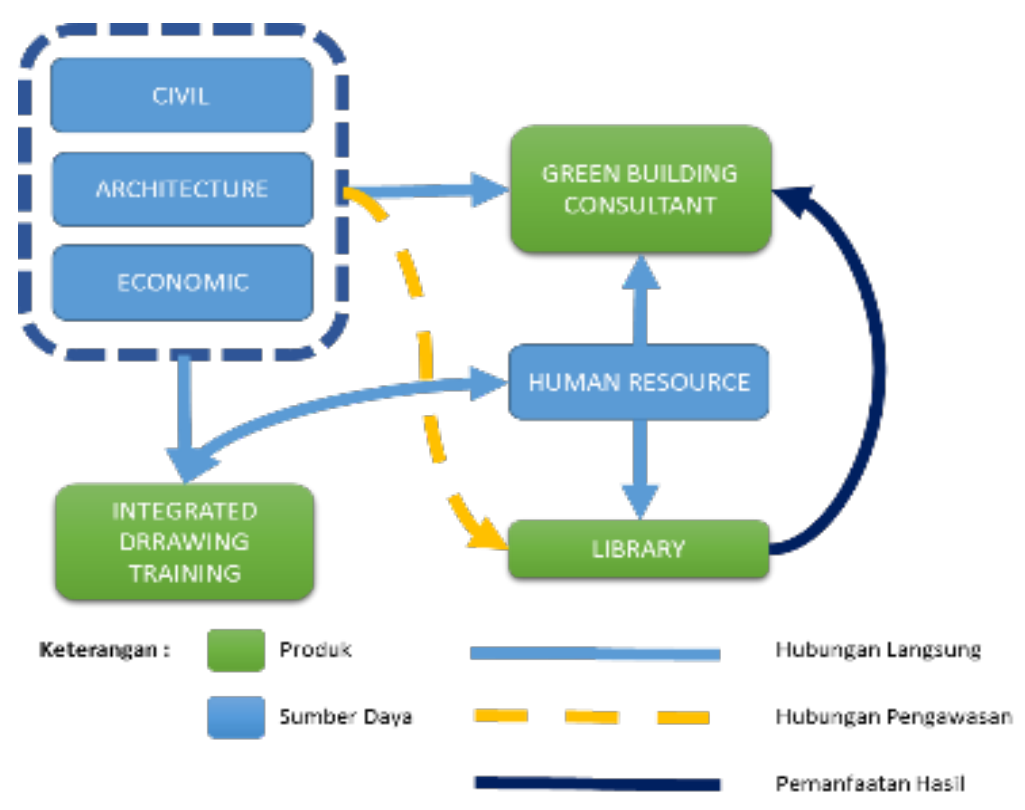

Gambar 1. Produk PPUPIK Konsultan GBWIKA dan keterkaitannya

\section{Green Building Consultant}

Green Building Consultant merupakan produk jasa utama. Jasa ini memberikan konsultasi untuk kebutuhan proyek atau pemilik proyek untuk menjadikan proyek yang ramah lingkungan dengan indikasi mendapatkan penilaian Greenship sesuai dengan yang ditargetkan oleh proyek atau gedung.

\section{Green Building Training}


Menjadi perwakilan dari Green Buiding Council Indonesia merupakan strategi untuk meningkatkan kapasitas sebagai profesional di bidang gedung ramah lingkungan juga sebagai strategi untuk memperkenalkan diri sebagai konsultan Green Building.

\section{Pelatihan Gambar (Autodesk \& Google Software)}

Melakukan training tenaga kerja yang terintegrasi untuk penunjang kebutuhan konsultan. Materi yang diajarkan meliputi pemodelan, dan simulasi perhitungan aspek bangunan hijau. Pelatihan ini merupakan produk pendamping utama.

\section{Konsultan Desain Bangunan Berbasis BIM}

Dalam pengerjaan proyek selalu membutuhkan tenaga drafter, diharapkan kami dapat mengahsilkan tenaga yang dibutuhkan, dengan kemampuan tambahan dari pelatihan kami. Diusahakan kami juga yang mengerjakan gambarnya, karena potensi peralatan dan fasilitas kami juga memadai (Pusat Penanggulangan Krisis Kesehatan, Kemenkes RI. 2015).

Tujuan

Dengan terbentuknya unit bisnis ini diharapkan terutama menjadi income generated untuk perguruan tinggi pada umumnya dan program studi pada khususnya. Tetapi ada beberapa hal juga yang dapat dicapai, diantaranya :

1. Sebagai pusat pengetahuan yang berhubungan dengan Green Building untuk ditingkatan dosen.

2. Sebagai wadah untuk para mahasiswa untuk mempelajari lebih jauh tentang Green Building. Sebagai tempat magang dan mendapatkan pengetahuan implementasi Green Building di proyek.

3. Mendukung visi program studi yang menuju ke pembangunan ramah lingkungan.

4. Menambah dan meningkatkan sarana dan prasarana untuk melakukan kegiatan atau eksperimen yang berhubungan dengan Green Building.

\section{MASALAH}

Pada kegiatan PPUPIK mengalami beberapa kendala, baik kendala secara internal maupun eksternal. Beberapa kendala itu adalah:

1. Sumber daya manusia dalam bidang green building masih terbatas. Terutama di Surabaya dan sekitarnya. 
2. Secara global tentang kebutuhan green building sudah besar. Karena masih kurangnya pengetahuan para pelaku pasar. Mereka masih enggan menerapkan.

3. Masih terbatasnya jaringan untuk mengembangkan konsep green building, terutama di Surabaya dan sekitarnya.

\section{METODE PELAKSANAAN}

Dalam menjalankan unit bisnis ini beberapa hal yang dilaksanakan mulai dari membangun pangsa pasar, meningkatkan kompetensi sumber daya manusia, menjalin hubungan komunikasi dengan kelompok aktifis green building, dan kemudian mengembangkan kemampuan (Kementrian Pekerjaan Umum dan Perumahan Rakyat Republik Indonesia, 2015).

\section{Membangun Pangsa Pasar}

Dalam setiap bisnis, membangun pangsa pasar merupakan yang terpenting. Mengedukasi pasar tentang pentingnya green building dan keuntungan bagi yang menerapkan. Selain pangsa pasar tentang green building, GBWIKA juga melayani konsultasi desain bangunan seperti pada umumnya.

Untuk menyosialisasikan hal ini GBWIKA membuat video penjelasan tentang Green Building, dan diunggah di You Tube Channel milik GBCI.

Selain itu GBWIKA aktif mengikuti pameran dan mengadakan talk show tentang Green Building di acara tersebut. Beberapa pameran yang diikuti diantaranya, Indobuildtech, Decortintex, Mega Build, dan Pameran Informasi Bahan Bangunan yang diadakan oleh Dinas Pekerjaan Umum dan Perumahan Rakyat, Provinsi Jawa Timur. Dari pameran tersebut kita melakukan tindak lanjut, sehingga dapat dikenal oleh pasar.

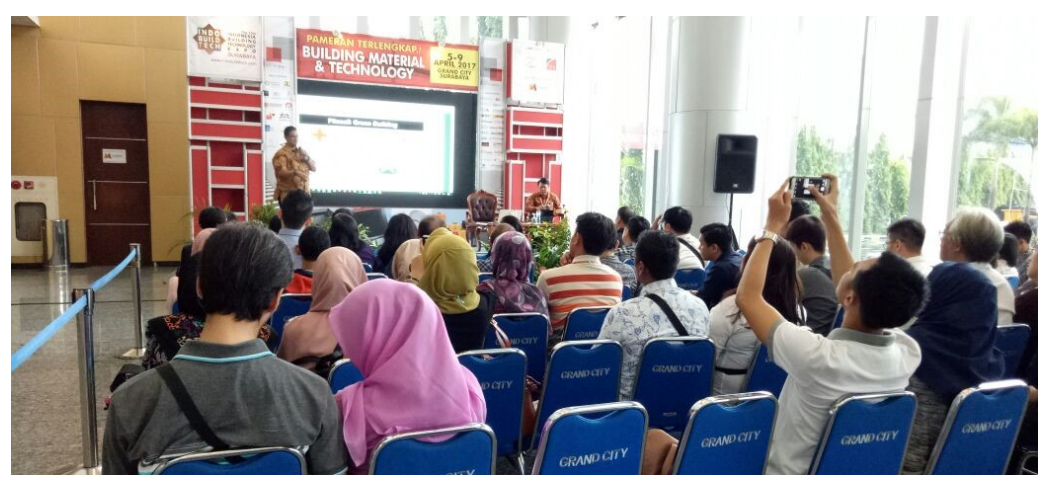

Gambar 2. Talkshow di salah satu pameran

Tindak lajut yang dilakukan adalah mengirimkan Profil Perusahaan dan melakukan presentasi ke perusahaan yang tertarik. 


\section{Meningkatkan Kompetensi Sumber Daya Manusia}

Peningkatan kompetensi Sumber Daya Manusia sangat diperlukan, apalagi memang bidang ini adalah bidang baru. GBWIKA memang menuntut seluruh yang terlibat dalam kegiatan memiliki pengetahuan tentang Green Building, supaya ada komunikasi yang baik. Baik pelaksana, anggota ataupun pegawai GBWIKA ditingkatkan pengetahuannya, baik melalui, workshop, kegiatan, dan pelatihan bersertifikasi.

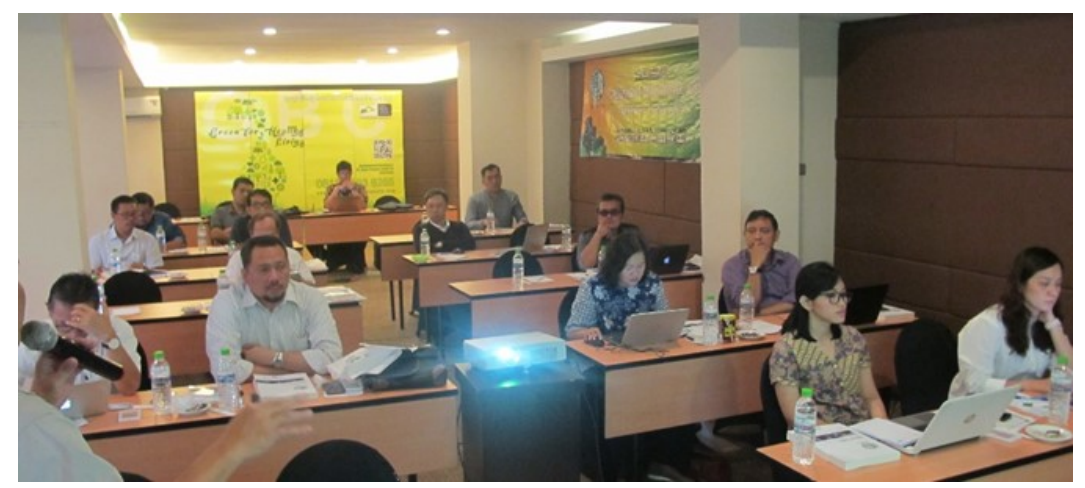

Gambar 4. Pelatihan bersertifikasi Greenship Profesional

Dengan peningkatan kompetensi ini, saat Green Building Widya Kartika memiliki sumber daya manusia sebagai berikut:

Tabel 1. Sumber Daya Manusia GBWIKA

\begin{tabular}{|c|c|c|c|}
\hline No & Nama & Bidang & Kompetensi \\
\hline \multicolumn{4}{|c|}{ Dosen Tetap UWIKA } \\
\hline 1. & $\begin{array}{l}\text { Ary Dwi Jatmiko, ST., } \\
\text { MT. }\end{array}$ & Arsitektur & $\begin{array}{l}\text { - Arsitektur } \\
\text { - Arsitektur Hijau } \\
\text { - Manajemen Organisasi } \\
\text { - Perancangan Produk Industri } \\
\text { - Computer Aided Design Autodesk } \\
\text { - International Certified } \\
\text { - Manajemen Produk dan Industri } \\
\text { - Greenship Profesional }\end{array}$ \\
\hline 2. & Agustinus Angkoso, ST. & Sipil & $\begin{array}{l}\text { - Sipil } \\
\text { - Perencanaan dan Perancangan } \\
\text { Struktur } \\
\text { - Dosen Computer Aided Design } \\
\text { - Greenship Associate }\end{array}$ \\
\hline 3. & Yulia Setyarini, SE., Mak. & Akuntansi & $\begin{array}{l}\text { - Akuntansi } \\
\text { - Perpajakan } \\
\text { - Manajemen keuangan } \\
\text { - Menguasai Accurate }\end{array}$ \\
\hline 4. & Dwi Taufik Hidayat, ST., & Informatika & - Sistem Informasi \\
\hline
\end{tabular}


M.Kom.

5. Ririn Dina Mutfianti, ST., Arsitektur MT.

Tenaga Ahli di luar UWIKA

6. Totok Soehartanto, DEA

7. Norman Ray, ST., MT.

Sipil

8. Ronny D. Nishan, ST. MT.

9. Reny Widya Lestrari, ST.

10. Marini, M.Psi., Psikolog

\section{Alumni UWIKA}

11. Oscar Ryo Luinuardy, ST.

12. Shinta Diah Permasari, ST.

13. Wendy Saputra

14. Yongki Kurniawan

15. Erly Karonia I. C. P.

16. Yomas Eliakim

17. Haris Tanayo

Mahasiswa UWIKA

18. Stephanus Lim Jaya

19. Richard Rafael Candra

Arsitektur

Arsitektur

Sipil
- Mobile Application Developer

- Data base

- Programing

- Arsitektur landsekap

- Konseptual desain

- Vegetasi

- Greenship Associate

Tek. Fisika • Instrumentasi

- Energi auditor

- Plumbing

- Greenship Profesional

- Perencanaan Stuktur

- Perhitungan struktur

- Simulasi struktur

Arsitektur - Arsitektur Madya

- Pemetaan

- Manajemen Konstruksi

- Surveyor

- Greenship Associate

- Arsitektur Madya

- Networking

- Sumber Daya Manusia

- SDM Training

- Greenship Associate

- Building Information Modeling

- Building design

- Greenship Associate

- Building design

- Arsitektur data

- Greenship Associate

Arsitektur - BIM Specialist

- Greenship Profesional

Arsitektur - BIM Modeler

- Greenship Associate

Arsitektur $\quad$ Building design

- Arsitektur data

- Greenship Associate

- BIM Modeler

- BIM Modeler

Arsitektur - BIM Modeler

- Greenship Associate

- BIM Modeler 
20. Vintencius Christian K.

21. Rosalina Febriani Santoso

22. Johan Sebastian Kihong

23. Isbran Trifosa S.

24. Luthfiyyatul Muqsithoh

25. Villa Navida Devi
Sipil

Sipil

Arsitektur

Arsitektur

\section{Mahasiswa Luar UWIKA}

26. Nandhita

Arsitektur

- BIM Modeler

- BIM Modeler

- BIM Modeler

- BIM Modeler

- BIM Modeler

- BIM Modeler

Dengan sumber daya seperti yang disampaikan di atas, GBWIKA memiliki kompetensi yang cukup untuk bersaing di industri konstruksi dengan basis Green Building dan Building Information Modeling

\section{Menjalin Hubungan dengan Komunitas Green Building}

Kami berusaha terlibat dalam green movement yang ada di Indonesia, terutama di daerah Surabaya dan sekitarnya. Aktifitas green movement di Indonesia sangat banyak, kami mengkhususkan sesuai dengan kompetensi, yaitu di bidang bangunan. Unit GBWIKA ini bergabung sebagai anggota di Green Building Council Indonesia (GBCI). GBCI adalah sebuah lembaga nir laba di luar pemerintahan yang merupakan anggota dari World Green Building Council, yang terpusat di Toronto, Kanada.

Dengan aktif di komunitas Green Building, akhirnya Green Building Council Indonesia menunjuk Ay Dwi Jatmiko sebagai representatif di Surabaya dan sekitarnya. Sehingga semua informasi tentang Green Building, pelatihan, workshop, sosialisasi, dan sertifikasi keahlian dapat dikelola, meskipun

\section{Pengembangan Sarana dan Prasarana serta Kompetensi}

Untuk menunjang kegiatan Green Building Widya Kartika diperlukan penambahan sarana dan prasarana. Pengembangan ini didukung dari keuntungan proyek yang dilaksanakan. Selain kompetensi di bidang Green Building, kami juga mendalami Building Information Modeling untuk kebutuhan simulasi Green Building. Dimana hal ini juga menunjang untuk kebutuhan desain, perancangan, kontrol dan pengawasan. Sehingga keahlian ini dapat bergunak untuk kebutuhan proyek konstruksi secara umum.

\section{PEMBAHASAN}

Semua kegiatan yang dilakukan oleh PPUPIK Jasa Konsultasi Green Building Universitas Widya Kartika, beragam dan melibatkan banyak pihak. Beberapa kegiatan juga 
mengalami beberapa kendala, tetapi dapat dilaksanakan. Saat ini pada tahun 2018 sangat terasa hasil yang didapat, karena telah menjadi konsultan green building yang pertama dan satu-satunya di Surabaya dan sekitarnya, bahkan di Indonesia Timur.

Tujuan untuk menjadi income generated bagi perguruan tinggi, telah dapat dirasakan pada tahun ke dua, berikut ini pekembangan omzet dan keuntungan bagi GBWIKA.

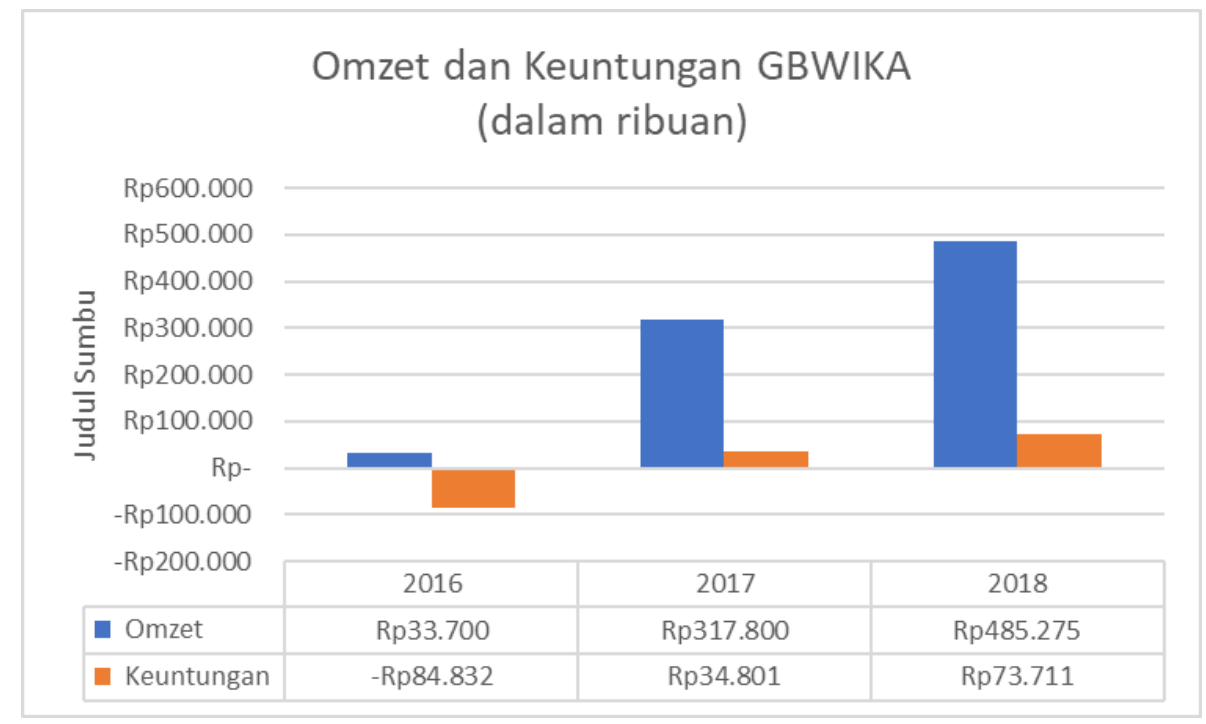

Gambar 5. Grafik Omzet dan Keuntungan GBWIKA

\section{KESIMPULAN}

Beberapa hal yang penting untuk dilakukan dalam pelaksanaan PPUPIK yang sejenis ini adalah peningkatan kompetensi SDM, berperan aktif dalam komunitas, melakukan sosialisasi ke pangsa pasar, termasuk memberikan sedikit ilmu terhadap bidang yang dikuasai, dan tetap membangunhubungan dengan mereka. Lebih baik kalau menjadi pengurus komunitas yang sesuai dengan keahlian yang dituju. Unit bisnis ini dapat dikembangkan lebih lanjut, karena peluang masih banyak, pangsa pasar dan kebutuhan masih berkembang. Dan sebagai salah satu kelompok yang mengawali akan banyak mendapatkan keuntungan berupa pengalaman yang lebih.

\section{UCAPAN TERIMA KASIH}

Terima kasih kami ucapkan kepada Kementerian Riset, Teknologi dan Pendidikan Tinggi, atas dana pengabdian yang telah diberikan selama tahun 2016-2019, melalui program Pengabdian Masyarakat skema Program Pengembangan Usaha Produk Intelektual Kampus (PPUPIK). Kami saat ini memiliki unit usaha yang siap bersaing dengan pihak luar, baik dalam negeri maupun luar negeri. Kami ucapkan juga kepada para kolega yang 
telah bekerjasama dengan kami, Green Building Widya Kartika, yang tidak dapat disebutkan satu persatu.

\section{DAFTAR PUSTAKA}

Kementrian Pekerjaan Umum dan Perumahan Rakyat Republik Indonesia. , (2015).

Nofiyanti, F., Sulartiningrum, S., \& Fitriana, R. (n.d.). Pelatihan Peningkatan Kualitas SDM Bidang Pariwisata di Desa Wisata Cikolelet Serang Banten. Jurnal SOLMA. https://doi.org/, [S.1.], v. 7, n. 2, p. 176-181, oct. 2018. ISSN 2614-1531. Available at: $<$ https://journal.uhamka.ac.id/index.php/solma/article/view/2228>. Date accessed: 02 may 2019. doi: https://doi.org/10.29405/solma.v7i2.2228

Pusat Penanggulangan Krisis Kesehatan, Kemenkes RI. http://www.penanggulangankrisis.depkes.go.id. 26 Januari 2015. 30 April 2015. (n.d.).

Salanto, F. (2015). Kompas.

www.YouTube.com. https://www.youtube.com/watch?v=DitBPAkFQUE, diakses $31 \mathrm{O}$. 2018. (n.d.). Green Building Council Indonesia. Apa itu Green Building?

\section{(c) (i)}

(C) 2019 Oleh authors. Lisensi Jurnal Solma, LPPM-Uhamka, Jakarta. Artikel ini bersifat open access yang didistribusikan di bawah syarat dan ketentuan Creative Commons Attribution (CC BY) license. (http://creativecommons.org/licenses/by/4.0/). 